\title{
ГЕРМЕНЕВТИКА (РЕ-)КОНСТРУЙОВАНОї ІСТОРИЧНОї ПАМ'ЯТІ: ДОСВІД ПОСТКОМУНІСТИЧНИХ КРАЇН
}

\begin{abstract}
Д.М. Шевчук
В посткомуністичних країнах Центрально-Східної Європи дискусії стосовно історичної пам'яті є надзвичайно актуальними, що перетворює їх на чинник, який впливає на життя суспільства та визначає характер політичних процесів. Важливість осмислення питань історичної пам'яті для цих країн пов'язане із утвердженням власної ідентичності та вирішенням питання так званої «перехідної (транзитної) справедливості». Останнє пов'язане із впровадженням програм перевірки й люстрації, обвинуваченням комуністичних лідерів та агентів комуністичних спецслужб, відкриттям секретних архівів для громадськості. Як правило, дослідники виокремлюють дві основні позиції у ставленні країн Центрально-Східної Європи до свого комуністичного минулого: «пробачити і забути» або «переслідувати і карати» [6]. Загалом же, специфіка вирішення як проблеми ставлення до комуністичного минулого, так і утвердження власної культурної (національної) ідентичності в посткомуністичних країнах, обумовлюється складністю феномену історичної пам'яті та особливостями сучасної культурної ситуації.

Історична пам'ять як колективна пам'ять може розумітися двояко. 3 одного боку, це спогади великої кількості індивідів тих подій, в яких вони безпосередньо брали участь. В даному контексті можна говорити про «масову персональну пам'ять». 3 іншого боку, це принципи, які використовуються національно свідомими індивідами для організації національної історії. У другому випадку ми маємо спра-
\end{abstract}

Актуальні проблеми духовності:

зб. наук. праць / Ред.: Я.В. Шрамко

Вип. 10. - Кривий Ріг, 2009, 360-367 
ву радше із певними «рамками», аніж змістом [5, с. 39-58]. Обидва ці типи, певною мірою, взаємопов'язані, оскільки досить часто в посткомуністичних країнах Центрально-Східної Європи через складний і суперечливий процес формування національної свідомості напередпокладеність змісту визначає принципи організації національної історії і навпаки. Ці складності і суперечності обумовлені також соціокультурною ситуацією, в яку потрапили країни Центрально-Східної Європи після розвалу комуністичного табору.

Пам'ять можна вважати одним із основних елементів культури. На це вказував, зокрема, Ю. Лотман, який писав: «Культура представляє собою колективний інтелект і колективну пам'ять, тобто надіндивідуальний механізм зберігання і передачі деяких повідомлень (текстів) і випрацювання нових. В цьому сенсі простір культури може бути представлений як простір певної пам'яті, тобто простір, в межах якого деякі загальні тексти можуть зберігатися і бути актуалізовані» [2, с.674]. Однак сучасність зумовлює ряд суперечностей культурної пам'яті. Фундаментальною суперечністю є те, що сучасна культура характеризується дуже короткою соціальною пам'яттю, з одного боку, і наявністю засобів, які дозволяють зберігати великі обсяги інформації, з іншого. Це, на наш погляд, зумовлено тим, що соціокультурні процеси нині відбуваються надзвичайно швидко, а домінування масової культури негативно впливає на традиції, які є дієвим механізмом культурної пам'яті. Можна припустити, що коротка соціальна пам'ять спричинена пануванням мас-медіа. Надмір смислів і інтерпретацій, які пропонують сучасні медіа, своєрідна «семіотична експансія», яку вони зумовили, та інтелектуальна невибагливість змісту повідомлень впливає на те, що смисли, витворені в рамках соціальної комунікації, не мають тенденції довго зберігатися. Звинувачення медіа в тому, що вони не сприяють збереженню пам'яті, можемо зустріти вже в Стародавній Греції. Так, Платон у діалозі «Федр» (275a) представляє ставлення Сократа до письма, яке, на думку філософа, спричиняє забування, оскільки людина перестає тренувати свою пам'ять. Сучасні мас-медіа, у свою чергу, підтримують існування маси - як писав Ж. Бодріяр, «чорної діри, яка поглинає усе соціальне», в тому числі й актуальні смисли $[1$, с. 8$]$.

Сучасна культура, з іншого боку, за допомогою тих же медіа створила засіб, який дозволяє зберігати великі обсяги інформації. Йдеться передусім про сучасні інформаційні технології. Але недостатня впорядкованість інформації через швидкість ії продукування за допомогою новітніх інформаційних технологій не дозволяє говорити про них 
як про дієвий механізм, що сприяє функціонуванню саме соціальної пам'яті.

Відтак, постає необхідність філософського осмислення проблем історичної пам'яті. Здійснити це можна за допомогою герменевтичного підходу. В сучасній соціальній філософії можемо зустріти поняття герменевтичної стратегії розуміння соціальної реальності. В центрі цієї стратегії знаходиться сфера інтерсуб'єктивності, яка вважається основою суспільства. Одним із її завдань є осягнення інтерсуб'єктивності соціальних значень, які проявляються в практиці комунікативних дій. Соціальна дія загалом при такому підході постає як творча інтерпретація, що здійснюється індивідами в процесі соціальної інтеракції. Таким чином, герменевтичний підхід дозволяє здійснити інтерпретацію феномену історичної пам'яті та, як наслідок інтерпретації, показати iї соціальне значення, а також механізми їі формування (у випадку посткомуністичних країн реконструювання або конструювання) і функціонування в процесі соціальної комунікації.

У випадку проблеми історичної пам'яті герменевтичний підхід застосовується, з одного боку, до історичної дійсності - розуміння передумов формування історичної пам'яті; а з іншого - до сучасного стану суспільства - розуміння актуального функціонування історичної пам'яті.

Герменевтика має значний досвід і необхідні засоби для розуміння соціально-історичної дійсності, що засвідчує передусім творчість В. Дільтея і Г.Шпета. Перетворивши герменевтику на методологічну основу гуманітарних наук (наук про дух), в центрі яких на початку XX ст. стояла історія, вони також окреслили можливість її застосовування до розуміння соціальних феноменів загалом. Феноменологічна герменевтика М. Хайдеггера та філософська герменевтика Г.-Г. Гадамера обгрунтували онтологічний статус розуміння, що дозволяє також використовувати герменевтику до витлумачення буттєвих основ суспільства.

Крім того, слід також зауважити, що сучасна герменевтика має досвід аналізу проблем пам'яті. Зокрема, до даної проблематики звертався французький філософ Поль Рікер у праці «Пам'ять, історія, забуття». Колективна пам'ять, на його думку, має етичний аспект, оскільки вона представляє собою пам'ять про моральний обов'язок здійснювати справедливість, або припускати можливість її втілення. Така ідея Рікера цілком підтверджує зв'язок історичної пам'яті в посткомуністичних країнах із проблемою «транзитної справедливості». Він підкреслює: «Здійснюючи хороші або погані вчинки, людина $є$ не просто індивідом, 
який відчуває тиск обставин, але мислячим суб'єктом, який, зіштовхуючись з перешкодою, споглядає власну ідентичність. Індивідуальна i колективна пам'ять, яка сприяє формуванню власної ідентичності, породжує проблему справедливої пам'яті. А поняття справедливої пам'яті набуває сенсу в результаті співставлення різних видів пам'яті» $[4$, c. 9]. У своїй герменевтичній феноменології пам'яті П. Рікер звертається до трагічного досвіду XX ст., який обтяжений пам'яттю насилля і страждання. Він стверджує, що можливі різні підходи до аналізу й оцінки історичних фактів, але в загальній системі оцінок і підходів завжди представлені проблеми моралі і справедливості.

Історичну пам'ять в герменевтичному аспекті можна розглядати як текст. При цьому слід пам'ятати, що культурний текст не $\epsilon$ предметом пасивного «споживання»; він конструюється з елементів доступних дискурсів, а також структурується через призму недискурсивних досвідів зі повсякденної інтеракції [7, с. 69]. Пам'ять набуває рис текстуальності і постає як елемент соціального дискурсу. Відтак, головна проблема, на яку слід звернути увагу в рамках герменевтичного підходу, - це проблема розуміння історичної пам'яті. Саме розуміння між учасниками соціального дискурсу $є$ ефективним засобом згоди щодо реалізації справедливості в процесі утвердження історичної пам'яті.

При цьому слід зауважити, що саме розуміння історичної пам'яті народжується в соціальному дискурсі. Причому це розуміння несе із собою інтуїцію істинності пам'яті. Істинна пам'ять - це не лише те, що було досягнуто в дискурсі і починає домінувати в ньому, але й те, що впорядковує (раціоналізує) дискурс. Історична пам'ять починає функціонувати в соціальній комунікації як регулятор соціальної дії, як чинник що її легітимізує. Зауважимо, що в даному випадку історична пам'ять найчастіше розуміється як система ціннісних суджень для розуміння теперішніх подій.

Історична пам'ять посттоталітарних країн $\epsilon$, з одного боку, реконструйованою, з іншого ж-конструйованою. Як реконструкція, так і конструювання історичної пам'яті відбувається на основі інтерпретації історичної дійсності. Остання спрямована на виявлення сенсу, який $\epsilon$ актуальним для сучасності і який має тенденцію до виконання функції впорядкування (організації) самого дискурсу.

Історична пам'ять посттоталітарних країн може бути реконструйованою через заклик повернення до джерел, до пам'яті про справжнє історичне минуле (тут реалізується своєрідне феноменологічне гасло, щоб добратися до істинної суті справ, або навіть утопічне прагнення «золотого віку», природного стану речей). Маємо тут справу із по- 
шуком своєї справжньої ідентичності. В посткомуністичних країнах можемо спостерігати постійні заклики відродити, відновити історичну пам'ять. Така реконструкція - це фактично реалізація герменевтичного принципу «прояснити, що насправді відбувалося». Як відомо, це гасло було виголошене представником німецької історичної школи Л. фон Ранке. Часто однак така реконструкція насправді є конструюванням.

Конструювання пам'яті можна розглядати крізь призму іншого герменевтичного принципу: «розуміти автора краще, ніж він сам себе розумів». Воно пов'язане із надбудовуванням смислів, своєрідною надінтерпретацією. В сучасній герменевтиці відбувся своєрідний генезис принципу надінтерпретації. Так, Ф. Шлейєрмахер, засновник сучасної герменевтики, стверджував, що автор ніколи не є для себе інтерпретатором, а тому слід зрозуміти різного роду несвідомі і приховані механізми, які впливають на творчість. Подібно з історичною епохою та пам'яттю про неї. Надінтерпретація, надбудовування смислів видається адекватним засобом для того, щоб проявити істинний стан речей.

Історична пам'ять конструюється на основі формування типізованих образів. Така типізація впроваджується в суспільний дискурс i, таким чином, конструює інтерактивні пояснення соціальних фактів. Пам'ять постає у вигляді символів, які відіграють роль смислових орієнтирів соціальної комунікації. Ці символи мають складну структуру, на що вказує П.Рікер в праці «Конфлікт інтерпретацій». Символ визначається французьким мислителем як знак, який відповідає певній речі, але разом з тим націлений за їі межі. Символ містить в собі подвійну інтенціональність: насамперед існує первинна, буквальна інтенціональність, яка передбачає перевагу умовного знаку по відношенню до природного знаку, а над первинною інтенціональністю надбудовується вторинна інтенціональність. П. Рікер зауважує, що «символічні знаки непрозорі, оскільки первинний, буквальний, явний смисл сам аналогічним чином націлений на вторинний смисл, який даний лише в ньому. Ця непрозорість приховує в собі глибину смислу» [3, с. 361]. Комунікативні символи, що функціонують в соціальному дискурсі, вводять учасників у сферу сенсів, в якій партнери конструюють значення.

Соціальна пам'ять функціонує в рамках дискурсів. При цьому слід зауважити той факт, що в сучасній культурі дискурси стали надзвичайно активними, що навіть важко вийти за їх межі. А тому своїх учасників вони затягують настільки, що проблемою постає не стільки пам'ять, скільки забування.

Забування загалом є природним явищем. Психологи стверджують, 
що організм передбачив можливість забування для того, щоб позбутися інформації, яка може приносити страждання і негативно впливати на психологічне здоров'я індивіда. Надмірна активність соціального дискурса історичної пам'яті в посткомуністичних країнах спричинили нав'язливість пам'яті, яка проявляється у тому, що вона перетворюється на мотив, який повторюється, навіть якщо намагаєшся його забути.

Таким чином, ми намагаємось дійти розуміння історичної дійсності в рамках соціального дискурсу, який, у свою чергу, насичений суперечностями. Для цього слід подолати конфлікти, що стає можливим, коли нам вдається знайти фундамент для порозуміння між учасниками дискурсу. Порозуміння може бути вибудуване на основі звернення до перед-розуміння. Йдеться про позадискурсивні елементи соціального буття. Цей рівень має не менше значення, аніж рівень дискурсу і подібно до останнього впливає на соціальну комунікацію. Як пише польська дослідниця Г. Воронєцка: «Позадискурсивні елементи соціальної комунікації, які характеризуються високим рівнем культурного оцінювання, визначають форму переконання про раціональність, принаймні на рівні з їі дискурсивним виміром» $[7$, с. 70$]$. Окрім цього, слід відмітити, що раціональність соціального дискурсу досить часто зумовлена, обумовлена і обгрунтована позадискурсивними елементами.

Позадискурсивний рівень пов'язаний із перед-розумінням історичної пам'яті. «Категорія ,перед-розуміння“ означає в філософській герменевтиці преорганізацію, що передує і обумовлює розуміння» $[7$, c. 86]. Перед-розуміння можемо представити в двох аспектах: по-перше, можемо віднести сюди непорозуміння (що може бути передумовою герменевтики, що також її уможливлює), по-друге, можемо розглядати його як недискурсивний досвід (замовчування, невисловлення історичної пам'яті).

Ідею герменевтики, як зауважував у своїх творах $Ф$. Шлейєрмахер, породило переконання, що досвід можливості непорозуміння є повсюдним. Труднощі і непорозуміння трактуються німецьким мислителем як щось очевидне, оскільки саме у ситуації непорозуміння повинна постати герменевтика.

Досить часто позадискурсивний рівень передбачає власний досвід, зокрема, трагедія сім'ї, сімейний досвід репресій. Цей досвід травматичний, замовчуваний (наприклад, більш-менш заможні селяни, яких в процесі колективізації «розкуркулювали», виселяли, відправляли на заслання. Пізніше, як правило, вони мовчали про це, навіть після реабілітації. Ця тема витіснялася не лише в соціальній комунікації, але 
й в особистій. Наявне тут також нерозуміння причин репресій). Трагічний досвід породжує переживання, які можуть стати передумовою для розуміння. Йдеться про спільність людських переживань. До цієї проблеми звертався, зокрема, В. Дільтей. Він використовував поняття об'єктивний дух, під яким розумів різноманітні форми, в яких спільнота, що існує між індивідами, об'єктивізувалась у чуттєвому світі. Сфера духу охоплює форми спілкування, звичаї, право, державу, релігію, мистецтво тощо. Об'єднання цих форм є певним зв'язком, в якому рухається історія. Об'єктивація внутрішнього досвіду стає доступною будь-якому члену спільноти, з недосяжного внутрішнього плану переходить у план того, що стає об'єктом розуміння.

Задля утвердження порозуміння щодо історичної пам'яті слід уникати неефективних, помилкових стратегій досягнення розуміння пам'яті в соціальному дискурсі. Одна з них - ситуативне виправдання, на зразок «тоді був такий час, інакше не можна було діяти». Відтак, відразу закладається монологічність відношення до Іншого, відкидання його, що передбачатиме конфлікт.

Іншою неефективною стратегією буде прикриття великим проектом. Це прикриття буде припускати, що реалізація грандіозного проекту може передбачати певні побічні наслідки. Можна було пожертвувати одним для того, щоб досягнути щастя мільйонів. Питання, яке ставить $\Phi$. Достоєвський у одному із своїх творів, чи можна пожертвувати життям немовляти, щоб досягнути щастя мільйонів? - тут однозначно має ствердну відповідь. Також в даному випадку допускається абстрактність розуміння конкретної людської долі. Постулюється переконаність у досвіді глибокої розірваності між дійсністю та будь-якою гуманістичною філософією.

Виправдання через проект передбачає також використання для цього позасвідомих механізмів, ствердження того, що певна особа виконувала лише свою соціальну функцію (службові обов'язки, накази). Безособовість соціальної функції розмиває переживання і відкидає можливість розуміння.

Нарешті, неефективною стратегією досягнення розуміння буде наполягання на очевидності. Історична пам'ять в рамках соціального дискурсу не може бути очевидною. Очевидність-це забуття. В філософії XX століття М. Хайдеггер стверджував ситуацію забуття буття, один із аспектів якого він пов'язував саме з очевидністю. Цим самим похитнув впевненість у тому, що очевидність є ознакою істинності, тобто переконання, яке було чітко сформульовано Р. Декартом. Очевидність історичної пам'яті-це радше феномен, який вказує на 
необхідність дошукуватися істини.

Загалом, осмислення феномену історичної пам'яті $є$ надзвичайно важливим для розуміння не лише дискусій щодо історії в посткомуністичних країнах, але також окреслення суті та механізмів функціонування ряду інших соціальних феноменів. Розгляд даної проблематики дозволяє нам краще зрозуміти питання легітимності соціальних інституцій, символічного позначення соціально-політичного простору та ін. На нашу думку, дієвий інструментарій для філософського осмислення феномену історичної пам'яті дає саме герменевтика. Ставлячи на перше місце проблему розуміння, герменевтика окреслює також шляхи досягнення розуміння в соціальному дискурсі та перетворення його на порозуміння серед учасників.

\section{1 Бібліог рафія}

[1] Бодрийар Ж. В тени молчаливого большинства, или Конец социального. - Екатеринбург: Издательство Уральского университета, 2000.

[2] Лотман Ю. Семиосфера. - СПб: Искусство-СПБ, 2000.

[3] Рикер П. Конфликт интерпретаций. Очерки о герменевтике / пер. с фр. И. Вдовина. - М., 2002.

[4] Рикер П. Память, история, забвение / пер. с фр. И.И.Блауберг, И.С. Вдовина, О.И. Мачульская, Г.М. Тавризян. - М., 2004.

[5] Snyder T. Memory of sovereignty and sovereignty over memory: Poland, Lithuania and Ukraine, 1939-1999 // Memory \& Power in Post-war Europe. Studies in the Presence of the Past / Ed. J.W. Müller. - Cambridge: Cambridge University Press, 2002. - P. 3958.

[6] Stan L. The Politics of Memory in Post-Communist Europe: A Comparative Analysis. - http://www.celat.ulaval.ca/histoire.memoire/ b2006/Stan.pdf.

[7] Woroniecka G. Interakcja symboliczna a hermeneutyczna kategoria przed-rozumienia. - Warszawa: Oficyna naukowa, 2003. 